\title{
Association study of MIF promoter polymorphisms with suicide completers in the Japanese population
}

\author{
This article was published in the following Dove Press journal: \\ Neuropsychiatric Disease and Treatment \\ 22 March 2017 \\ Number of times this article has been viewed
}

\author{
Naofumi Shimmyo' \\ Akitoyo Hishimoto' \\ Ikuo Otsuka' \\ Satoshi Okazaki' \\ Shuken Boku' \\ Kentaro Mouri' \\ Tadasu Horai ${ }^{\prime}$ \\ Motonori Takahashi \\ Yasuhiro Ueno ${ }^{2}$ \\ Osamu Shirakawa ${ }^{3}$ \\ Ichiro Sora' \\ 'Department of Psychiatry, ${ }^{2}$ Division \\ of Legal Medicine, Department of \\ Community Medicine and Social \\ Health Science, Kobe University \\ Graduate School of Medicine, Kobe, \\ ${ }^{3}$ Department of Neuropsychiatry, \\ Kindai University Faculty of Medicine, \\ Osaka, Japan
}

\begin{abstract}
Background: Numerous studies suggest that inflammation plays a key role in suicidal behavior. Macrophage migration inhibitory factor (MIF), a proinflammatory cytokine, has received increasing attention in depression research. However, no study has investigated whether MIF has genetic involvement in completed suicide. In this study, we sought to explore the relationship between two functional polymorphisms on the $M I F$ gene promoter $\left(M I F-794 \mathrm{CATT}_{5-8}\right.$ microsatellite and $M I F-173 \mathrm{G} / \mathrm{C}$ single-nucleotide polymorphism [SNP]) and completed suicide by using one of the largest samples of suicide completers ever reported.
\end{abstract}

Methods: The subjects comprised 602 suicide completers and 728 healthy controls.

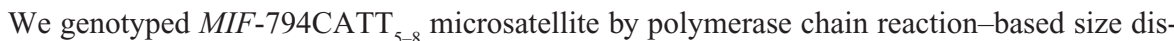
crimination assay and $M I F-173 \mathrm{G} / \mathrm{C}$ SNP by TaqMan ${ }^{\circledR}$ SNP genotyping assay. The allele-, genotype-, or haplotype-based association analyses between the suicide completers and the controls were carried out with the $\chi^{2}$ test, the Cochran-Armitage trend test, or Fisher's exact test.

Results: Analyses of allele or genotype frequency distributions of the polymorphisms studied here did not reveal any significant differences between the suicide completers and the controls. Haplotype analysis also revealed no association with completed suicide.

Conclusion: To our knowledge, this is the first study that has examined the genetic association between MIF and completed suicide. Our results suggest that the effects of MIF-794CATT microsatellite and $M I F-173 \mathrm{G} / \mathrm{C}$ SNP on the $M I F$ gene promoter might not contribute to the genetic risk of completed suicide in the Japanese population.

Keywords: MIF, suicide, microsatellite, SNP, haplotype, promoter region

\section{Introduction}

Suicide is a significant public health problem worldwide, with $\sim 1$ million suicides each year. A review of the literature showed that $>2 \%$ of the current traffic accidents were suicide attempts, and this phenomenon may be underreported. ${ }^{1}$ The involvement of genetic factors in suicidal behavior is supported by family studies, twin and adoption studies, candidate gene analyses, and genome-wide association studies. Various studies have shown that numerous genes (eg, serotonin receptors and transporters, brain-derived neurotrophic factors [BDNF], or catechol- $O$-methyltransferase [COMT]) are linked to suicidal behavior, although conflicting reports exist. ${ }^{2,3}$ In addition, recent studies reported aberrant cytokine levels in blood, cerebrospinal fluid, and postmortem brain samples from suicidal completers. ${ }^{4}$ For instance, increased blood levels of interleukin-6 (IL-6) and tumor necrosis factor- $\alpha$ (TNF- $\alpha$ ) are associated with suicidal ideation and attempt. ${ }^{5,6}$ Alternatively, mRNA and protein levels of IL-1 $\beta$, IL-6, and TNF- $\alpha$ were increased postmortem in the prefrontal cortexes of teenaged suicide completers. ${ }^{7}$
Correspondence: Akitoyo Hishimoto Department of Psychiatry, Kobe University Graduate School of Medicine, 7-5-I, Kusunoki-cho, Chuo-ku, Kobe 650-00I7, Japan

Tel +81783826065

Fax +8I 783826079

Email hishipon@med.kobe-u.ac.jp 
Macrophage migration inhibitory factor (MIF) is a pleiotropic cytokine involved in the regulation of innate and adaptive immunity. ${ }^{8}$ MIF was originally identified as a product of T-lymphocytes on the basis of its ability to prevent random migration of macrophages. ${ }^{9,10}$ MIF is secreted in response to inflammatory stimuli, including microbial products and glucocorticoids. ${ }^{11,12}$ Upon release, MIF acts in an autocrine and paracrine manner to promote proinflammatory cytokine production, eg, IL-1 $\beta$, IL-6, and TNF- $\alpha \cdot .^{13,14}$ MIF has also been shown to facilitate DNA damage response and cell cycle regulation. ${ }^{15}$ In addition, MIF production has been discovered in many other nonimmune cells ubiquitously, being highly expressed in the liver, kidneys, anterior pituitary, and brain. ${ }^{8,16}$ It is reported that $M I F$ expression in the brain was seen in neurons of the cortex, hypothalamus, hippocampus, cerebellum, and pons, ${ }^{17}$ and in astrocytes and the subgranular zone of the hippocampus. ${ }^{18}$ Increasing evidence suggests a role for MIF in depression. ${ }^{19}$ Deletion of MIF resulted in increased depressive behaviors in rodent models..$^{18}$ In addition, several studies have explored MIF as a biomarker in major depressive disorder (MDD) and other mood disorders. Some studies have identified increased serum MIF both in patients with MDD and in healthy subjects with depressive symptoms. ${ }^{20-22}$ Exhaustive serum proteomic profiling of MDD has identified MIF as one of the robust changed analytes in patients compared with controls..$^{23,24}$ Furthermore, it has been established that MIF has an intricate relationship with the hypothalamic-pituitary-adrenal axis. For instance, Edwards et $\mathrm{a}^{25}$ found that elevated serum MIF was associated with depressive symptoms, reduced cortisol response to acute stress, and lower morning cortisol values. Alternatively, MIF was shown to specifically counteract the glucocorticoid-induced suppression of inflammatory cytokine secretion in activated macrophages (IL-1 $\beta$, IL-6, and TNF- $\alpha$ ). ${ }^{12}$ The hypothalamic-pituitary-adrenal axis has also gained interest as a neurobiological factor related to suicide, on the basis of the findings of studies investigating dexamethasone suppression test (DST) response, since nearly a 10 -fold higher risk of completed suicide was found in DST nonsuppressors than in DST suppressors in a depressed cohort. ${ }^{2,26}$

From these findings, we hypothesized that MIF is involved in the genetic pathophysiology of suicide. The MIF gene promoter contains two functional variations: $M I F-$ 794CATT $_{5-8}$ repeat (rs5844572) and $M I F-173 \mathrm{G} / \mathrm{C}$ single-nucleotide polymorphism (SNP) (rs755622), which have been well documented to affect the gene expression and protein levels of MIF. ${ }^{27,28}$ Indeed, many studies have examined the association between these two polymorphisms and various physical diseases. ${ }^{29-34}$ However, no previous study has investigated the role of both these polymorphisms in suicidal behavior. Hence, we investigated the association of the two functional polymorphisms on the MIF promoter in suicide using the large sample size of 602 suicide completers and 728 controls.

\section{Materials and methods \\ Subjects}

This study was approved by the Ethical Committee for Genetic Studies of Kobe University Graduate School of Medicine. The study population consisted of 602 suicide completers (408 males: mean age \pm standard deviation (SD), 51.0 \pm 17.4 years; 194 females: $50.7 \pm 18.8$ years) and 728 unrelated healthy volunteers ( 340 males: mean age \pm SD, $53.3 \pm 18.8$ years; 388 females: $54.5 \pm 18.3$ years). All subjects were ethnically Japanese.

Autopsies on suicide victims were conducted at the Department of Legal Medicine, Kobe University Graduate School of Medicine. The definition of suicide was based on the results of medicolegal examination and the police investigation as required by Japanese law. The methods of suicide were neck hanging (399), jumping from heights (100), gas suffocation (29), drowning (16), jumping in front of a vehicle (9), drug overdose (8), self-inflicted penetrating wounds (8), self-burning (3), taking poison (2), other methods (10), and unknown (18). We subdivided suicide completers into violent suicide (neck hanging, jumping from heights, gas suffocation, drowning, jumping in front of a vehicle, self-inflicted penetrating wounds, and self-burning) and nonviolent suicide (taking poison and drug overdose), according to Dumais et al..$^{35}$ The healthy controls were recruited with consent after the purpose and procedures of the study were explained. The psychiatric assessment of each healthy participant was conducted as previously described. ${ }^{36,37}$ Briefly, none of them manifested psychiatric problems in unstructured interviews using unnamed symptom checklists based on the Diagnostic and Statistical Manual of Mental Disorders 4th edition criteria by two psychiatrists. Demographics of suicide completers and healthy controls are shown in Table 1. Informed consent was obtained from all of the participants and from the families of the subjects used for postmortem blood experiments.

\section{Blood and DNA sampling}

Peripheral blood was obtained from all suicide completers and controls. Blood samples were stored at $-80^{\circ} \mathrm{C}$ before use. DNA was extracted using the QIAamp DNA Blood Midi Kit (Qiagen Inc., Valencia, CA, USA). Each DNA sample was quantified and qualified using a NanoDrop spectrophotometer (Thermo Scientific, Wilmington, DE, USA). 
Table I Demographics of suicide completers and healthy controls

\begin{tabular}{lll}
\hline Subjects & $\begin{array}{l}\text { Suicide } \\
(\mathbf{n}=\mathbf{6 0 2})\end{array}$ & $\begin{array}{l}\text { Control } \\
(\mathbf{n}=\mathbf{7 2 8})\end{array}$ \\
\hline Mean age \pm SD & $50.9 \pm 17.9$ & $54.0 \pm 18.5$ \\
$\mathrm{n}$ (male:female) & $408: 194$ & $340: 388$ \\
Suicide methods & & \\
$\quad$ Neck hanging & 399 & \\
Jumping from heights & 100 & \\
Gas suffocation & 29 & \\
Drowning & 16 & \\
Jumping in front of vehicles & 9 & \\
Drug overdosing & 8 & \\
Self-inflicted penetrating wounds & 8 & \\
Self-burning & 3 & \\
Taking poison & 2 & \\
Other & 10 & \\
Unknown & 18 &
\end{tabular}

Abbreviation: SD, standard deviation.

\section{Genotyping for the MIF-794CATT ${ }_{5-8}$ repeat polymorphism (rs5844572)}

Genomic DNA (100 ng) was subjected to polymerase chain reaction (PCR) for one cycle at $95^{\circ} \mathrm{C}$ for 10 minutes, followed by 40 cycles at $95^{\circ} \mathrm{C}$ for 30 seconds, $55^{\circ} \mathrm{C}$ for 30 seconds, $72^{\circ} \mathrm{C}$ for 30 seconds and final extension at $72^{\circ} \mathrm{C}$ for 7 minutes. The forward primer was 5'-TTG-CAC-CTA-TCA-GAGACC $-3^{\prime}$ labeled with a carboxyfluorescein fluorescent dye, and the reverse primer was 5'-TCC-ACT-AAT-GGT-AAACTC-G-3'. The $25 \mu \mathrm{L}$ PCR reaction volume contained $100 \mathrm{ng}$ of genomic DNA, 12.5 $\mu \mathrm{L}$ of AmpliTaq Gold 360 Master Mix (Thermo Fisher Scientific, Waltham, MA, USA) and $1.0 \mu \mathrm{L}$ of forward and reverse primer. The amplification included an initial holding at $95^{\circ} \mathrm{C}$ for 10 minutes, followed by a three-step PCR program: $95^{\circ} \mathrm{C}$ for 30 seconds, $55^{\circ} \mathrm{C}$ for 30 seconds, and 40 cycles at $72^{\circ} \mathrm{C}$ for 30 seconds, and finally, $72^{\circ} \mathrm{C}$ for 7 minutes. The PCR product was appropriately diluted and supplemented with GeneScan 600 size standard (Applied Biosystems, Foster City, CA, USA). The mixture was then separated on a $50-\mathrm{cm}$ polyacrylamide gel at 15,000 V for 45 minutes on an ABI 3130 capillary sequencer and analyzed with GeneMapper ${ }^{\circledR} 4.0$ software (Applied Biosystems). The PCR product sizes were $207 \mathrm{bp}$, $211 \mathrm{bp}$, and $215 \mathrm{bp}$ in length, and these corresponded to 5-, 6-, and 7-CATT repeats, respectively. 8-CATT repeats were not observed in this study.

\section{Genotyping for the MIF-I73G/C SNP (rs755622)}

We selected the predesigned TaqMan SNP genotyping assays from the Applied Biosystems database (http:// www.appliedbiosystems.com) for the $M I F-173 \mathrm{G} / \mathrm{C}$ SNP (rs755622). Genotyping was performed with a 7500 RealTime PCR System (Applied Biosystems) according to the manufacturer's protocol.

\section{Statistics}

We used the Haploview version 4.2 software program (http:// www.broad.mit.edu/mpg/haploview) to determine the HardyWeinberg equilibrium and allelic or haplotype frequencies for each of the MIF promoter polymorphisms. ${ }^{38}$ The allele-, genotype-, or haplotype-based association analyses between the suicide and control groups were carried out with the $\chi^{2}$ test, Cochran-Armitage trend test, or Fisher's exact test, as appropriate, using Haploview software, $\mathrm{R}$ version 3.1.0 (The R Foundation for Statistical Computing, 2014, Vienna, Austria) and Excel 2010 (Microsoft, Redmond, WA, USA) with the Statcel3 add-on (OMS, Saitama, Japan). The power analysis was performed with the PS v2.1.3.1 program. ${ }^{39}$ Statistical significance for the two $M I F$ polymorphisms study was defined as two-tailed $P<0.05 / 2=0.025$.

\section{Results \\ MIF-794CATT ${ }_{5-8}$ repeat and MIF-I 73G/C SNP analyses}

No deviation from Hardy-Weinberg equilibrium was seen in suicide completers and healthy controls for both polymorphisms. The $M I F-794 \mathrm{CATT}_{5-8}$ repeat genotype and allele frequencies are shown in Table 2. Neither the genotype distribution nor the allelic frequency of the polymorphism was significantly associated with completed suicide. The $M I F-173 G / C$ SNP genotype and allele frequencies in suicide completers and healthy controls are shown in Table 3. Neither the genotype distribution nor the allelic frequency of the SNP was significantly associated with completed suicide. Subgroup analyses based on sex difference or methods of suicide (violent or nonviolent) also yielded no significant findings (Tables S1-S5).

\section{MIF promoter haplotype analyses}

Linkage disequilibrium between each CATT repeat and the $-173 \mathrm{C}$ was measured as follows: $\mathrm{CATT}_{5}$ and $-173 \mathrm{C}$ : $\mathrm{D}^{\prime}=0.495, r^{2}=0.043 ; \mathrm{CATT}_{6}$ and $-173 \mathrm{C}: \mathrm{D}^{\prime}=0.871$, $r^{2}=0.170 ; \mathrm{CATT}_{7}$ and $-173 \mathrm{C}: \mathrm{D}^{\prime}=0.984, r^{2}=0.678$. The $\mathrm{CATT}_{7}$ and $-173 \mathrm{C}$ polymorphisms were observed in strong linkage disequilibrium in our samples. We then examined whether the different haplotypes of the MIF-794CATT ${ }_{5-8}$ repeat and the $M I F-173 \mathrm{G} / \mathrm{C}$ SNP would show different distribution patterns in suicide completers compared with controls. The reconstructed frequencies of each possible haplotype based on the observed genotype data are shown 
Table 2 Association of MIF-794CATT ${ }_{5-8}$ repeat with suicide completers and controls

\begin{tabular}{|c|c|c|c|c|c|c|c|c|}
\hline \multirow[t]{2}{*}{ Polymorphism } & \multicolumn{2}{|c|}{ Suicide $(n=602)$} & \multicolumn{2}{|c|}{ Control $(n=728)$} & \multirow[t]{2}{*}{$P$-value ${ }^{a}$} & \multirow{2}{*}{$\begin{array}{l}\text { Global } \\
\text {-value }^{\text {b }}\end{array}$} & \multirow[t]{2}{*}{ OR $(95 \% \mathrm{Cl})$} & \multirow[t]{2}{*}{ Power } \\
\hline & $\mathbf{N}$ & Frequency & $\mathbf{N}$ & Frequency & & & & \\
\hline \multicolumn{9}{|l|}{ MIF-794CATT ${ }_{5-8}$} \\
\hline \multicolumn{9}{|l|}{ Genotype } \\
\hline 55 & 86 & 0.143 & 105 & 0.145 & 0.943 & 0.409 & $0.99(0.73-1.35)$ & 0.050 \\
\hline 56 & 231 & 0.384 & 251 & 0.345 & 0.141 & & $1.18(0.95-1.48)$ & 0.313 \\
\hline 57 & 77 & 0.128 & 95 & 0.130 & 0.889 & & $0.98(0.7 \mathrm{I}-\mathrm{I} .35)$ & 0.051 \\
\hline 66 & III & 0.184 & 158 & 0.217 & 0.140 & & $0.82(0.62-1.07)$ & 0.319 \\
\hline 67 & 83 & 0.138 & 93 & 0.128 & 0.587 & & $1.09(0.79-1.50)$ & 0.084 \\
\hline 77 & 14 & 0.023 & 26 & 0.036 & 0.185 & & $0.64(0.33-1.24)$ & 0.277 \\
\hline \multicolumn{9}{|l|}{ Allele } \\
\hline $\mathrm{CATT}_{5}$ & 480 & 0.399 & 556 & 0.382 & 0.376 & 0.645 & $1.07(0.92-1.25)$ & 0.146 \\
\hline CATT $_{6}$ & 536 & 0.445 & 660 & 0.453 & 0.675 & & $0.97(0.83-1.13)$ & 0.070 \\
\hline $\mathrm{CATT}_{7}$ & 188 & 0.156 & 240 & 0.165 & 0.544 & & $0.94(0.76-1.15)$ & 0.096 \\
\hline
\end{tabular}

Notes: ${ }^{a} G$ enotypic $P$-values and allelic $P$-values were tested with the $\chi^{2}$ test. ' $G$ lobal $P$-values were calculated by Fisher's exact test.

Abbreviations: MIF, macrophage migration inhibitory factor; $\mathrm{OR}$, odds ratio; $\mathrm{Cl}$, confidence interval.

in Table 4. There were six haplotypes in this study, none of which showed different distributions between suicide completers and controls. Subgroup analyses based on sex difference or methods of suicide (violent or nonviolent) also showed no significance (Tables S1-S5).

\section{Discussion}

To our knowledge, this is the first study to investigate the association between suicide and two functional polymorphisms in the MIF gene promoter, which are known to affect the gene expression and protein levels of MIF. We also conducted subgroup analysis to investigate sex differences because males tend toward a higher suicide rate than females do among all age groups worldwide. ${ }^{40}$ Furthermore, we determined differences between violent and nonviolent suicides in this study because lethality associated with violent methods is considerably higher than that associated with nonviolent methods. ${ }^{41}$ Moreover, some previous studies showed differences between subjects with violent vs nonviolent methods of suicide in other polymorphisms (for the
COMT and BDNF genes) related to completed suicide. ${ }^{42,43}$ As a result, no significant differences were found in any of the analyses, which indicated that $M I F-794 \mathrm{CATT}_{5-8}$ repeat microsatellite and $M I F-173 \mathrm{G} / \mathrm{C}$ SNP are not associated with an increased risk of suicide in the Japanese population. Recent meta-analyses with MDD cases also failed to show the genetic involvement of $M I F{ }^{44,45}$ Therefore, MIF might not be primarily involved in genetic susceptibility to suicide (and depression).

The limitations of the present study should be considered. First, the current sample provides low powers based on the observed frequencies of two polymorphisms. The number of subjects in the association study may not have been large enough to detect a significant difference, although our sample size of suicide completers was one of the largest ever reported. In fact, most previous candidate gene analyses and genome-wide association studies for completed suicide could not overcome the statistical limitation of small samples s $^{2,3,46}$ because it is extremely difficult to obtain tissue samples from suicide completers. Second, our study included only the

Table 3 Association of MIF-I73 SNP with suicide completers and controls

\begin{tabular}{|c|c|c|c|c|c|c|c|c|}
\hline \multirow[t]{2}{*}{ Polymorphism } & \multicolumn{2}{|c|}{ Suicide $(n=602)$} & \multicolumn{2}{|c|}{ Control $(n=728)$} & \multirow[t]{2}{*}{$P$-value ${ }^{a}$} & \multirow{2}{*}{$\begin{array}{l}\text { Global } \\
P \text {-value }\end{array}$} & \multirow[t]{2}{*}{ OR (95\% CI) } & \multirow[t]{2}{*}{ Power } \\
\hline & $\mathbf{N}$ & Frequency & $\mathbf{N}$ & Frequency & & & & \\
\hline \multicolumn{9}{|l|}{ MIF-I73G/C } \\
\hline \multicolumn{9}{|l|}{ Genotype } \\
\hline GG & 373 & 0.620 & 451 & 0.619 & 0.997 & $0.7 \mid 4$ & $\mathrm{I} .00(0.83-\mid .2 \mathrm{I})$ & 0.050 \\
\hline GC & 203 & 0.337 & 237 & 0.326 & 0.653 & & $\mathrm{I} .05(0.84-\mathrm{I} .33)$ & 0.071 \\
\hline CC & 26 & 0.043 & 40 & 0.055 & 0.326 & & $0.78(0.47-1.29)$ & 0.168 \\
\hline \multicolumn{9}{|l|}{ Allele } \\
\hline G & 949 & 0.788 & 1,139 & 0.782 & 0.711 & & $0.97(0.80-1.16)$ & 0.066 \\
\hline C & 255 & 0.212 & 317 & 0.218 & & & & \\
\hline
\end{tabular}

Notes: aGenotypic $P$-values and allelic $P$-values were tested with the $\chi^{2}$ test. ${ }^{b} G$ lobal $P$-value was tested with the Cochran-Armitage test for trend. Abbreviations: MIF, macrophage migration inhibitory factor; $\mathrm{OR}$, odds ratio; $\mathrm{Cl}$, confidence interval. 
Table 4 Association of haplotypes of MIF promoter polymorphisms with suicide completers and controls

\begin{tabular}{|c|c|c|c|c|c|c|c|c|}
\hline \multirow[t]{2}{*}{ Haplotype } & \multicolumn{2}{|c|}{ Suicide $(n=602)$} & \multicolumn{2}{|c|}{ Control $(n=728)$} & \multirow[t]{2}{*}{$P$-value ${ }^{a}$} & \multirow{2}{*}{$\begin{array}{l}\text { Global } \\
P \text {-value }\end{array}$} & \multirow[t]{2}{*}{ OR (95\% Cl) } & \multirow[t]{2}{*}{ Power } \\
\hline & $\mathbf{N}$ & Frequency & $\mathbf{N}$ & Frequency & & & & \\
\hline \multicolumn{9}{|l|}{ Haplotype } \\
\hline MIFCATT $_{5}-173 \mathrm{G}$ & 427 & 0.355 & 496 & 0.341 & 0.442 & 0.631 & $1.06(0.90-1.25)$ & 0.118 \\
\hline MIFCATT $_{6}-173 \mathrm{G}$ & 522 & 0.433 & 641 & 0.440 & 0.716 & & $0.97(0.83-1.13)$ & 0.065 \\
\hline 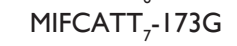 & 4 & 0.003 & I & 0.001 & 0.129 & & $4.14(0.54-31.7)$ & 0.229 \\
\hline MIFCATT $_{5}-173 \mathrm{C}$ & 53 & 0.044 & 60 & 0.041 & 0.746 & & $1.06(0.73-1.55)$ & 0.068 \\
\hline MIFCATT $_{6}-173 \mathrm{C}$ & 14 & 0.012 & 19 & 0.013 & 0.802 & & $0.92(0.46-1.84)$ & 0.055 \\
\hline MIFCATT, $_{7}-173 \mathrm{C}$ & 184 & 0.153 & 239 & 0.164 & 0.426 & & $0.92(0.75-1.13)$ & 0.096 \\
\hline
\end{tabular}

Notes: a ${ }^{P}$-values were tested with the $\chi^{2}$ test. ' ${ }^{b}$ Global $P$-value was calculated by Fisher's exact test or Cochran-Armitage test for trend, as appropriate.

Abbreviations: MIF, macrophage migration inhibitory factor; OR, odds ratio; $\mathrm{Cl}$, confidence interval.

Japanese population. The distribution of MIF polymorphisms determined by us was similar to that determined in the previous study for Japanese population by Llamas-Covarrubias et al ${ }^{47}$ but not for Caucasian by Swanberg et al. ${ }^{48}$ Given that the MIF polymorphisms studied here differ among Caucasians, Africans, and Asians ${ }^{49}$ our results might not be extrapolated to other populations. In addition, MIF protein levels in the brains of individuals displaying suicidal behavior should be further investigated to clarify the associations between MIF and suicide other than genetic susceptibility.

\section{Conclusion}

In conclusion, our results suggest that $M I F-794 \mathrm{CATT}_{5-8}$ microsatellite and $M I F-173 \mathrm{G} / \mathrm{C}$ SNP microsatellite might not contribute to the genetic risk of completed suicide in the Japanese population.

\section{Acknowledgments}

This work was supported in part by JSPS KAKENHI (Grant Number JP26461718). We thank Yasuko Nagashima for providing technical assistance.

\section{Disclosure}

The authors report no conflicts of interest in this work.

\section{References}

1. Pompili M, Serafini G, Innamorati M, et al. Car accidents as a method of suicide: a comprehensive overview. Forensic Sci Int. 2012;223:1-9.

2. Oquendo MA, Sullivan GM, Sudol K, et al. Toward a biosignature for suicide. Am J Psychiatry. 2014;171:1259-1277.

3. Mirkovic B, Laurent C, Podlipski MA, Frebourg T, Cohen D, Gerardin P. Genetic association studies of suicidal behavior: a review of the past 10 years, progress, limitations, and future directions. Front Psychiatry. 2016;7:158.

4. Ganança L, Oquendo MA, Tyrka AR, Cisneros-Trujillo S, Mann JJ, Sublette ME. The role of cytokines in the pathophysiology of suicidal behavior. Psychoneuroendocrinology. 2016;63:296-310.

5. Janelidze S, Mattei D, Westrin $\AA$, Träskman-Bendz L, Brundin L. Cytokine levels in the blood may distinguish suicide attempters from depressed patients. Brain Behav Immun. 2011;25:335-339.
6. O'Donovan A, Rush G, Hoatam G, et al. Suicidal ideation is associated with elevated inflammation in patients with major depressive disorder. Depress Anxiety. 2013;30:307-314.

7. Pandey GN, Rizavi HS, Ren X, et al. Proinflammatory cytokines in the prefrontal cortex of teenage suicide victims. J Psychiatr Res. 2012;46:57-63.

8. Calandra T, Roger T. Macrophage migration inhibitory factor: a regulator of innate immunity. Nat Rev Immunol. 2003;3:791-800.

9. Bloom BR, Bennett B. Mechanism of a reaction in vitro associated with delayed-type hypersensitivity. Science. 1966;153:80-82.

10. David JR. Delayed hypersensitivity in vitro: its mediation by cell-free substances formed by lymphoid cell-antigen interaction. Proc Natl Acad Sci U S A. 1966;56:72-77.

11. Bernhagen J, Calandra T, Mitchell RA, et al. MIF is a pituitary-derived cytokine that potentiates lethal endotoxaemia. Nature. 1993;365: 756-759.

12. Calandra T, Bernhagen J, Metz CN, et al. MIF as a glucocorticoidinduced modulator of cytokine production. Nature. 1995;377:68-71.

13. Bacher M, Metz CN, Calandra T, et al. An essential regulatory role for macrophage migration inhibitory factor in T-cell activation. Proc Natl Acad Sci U S A. 1996;93:7849-7854.

14. Calandra T, Bernhagen J, Mitchell RA, Bucala R. Macrophage is an important and previously unrecognized source of macrophage-migration inhibitory factor. J Exp Med. 1994;179:1895-1902.

15. Flaster H, Bernhagen J, Calandra T, Bucala R. The macrophage migration inhibitory factor-glucocorticoid dyad: regulation of inflammation and immunity. Mol Endocrinol. 2007;21:1267-1280.

16. Kleemann R, Hausser A, Geiger G, et al. Intracellular action of the cytokine MIF to modulate AP-1 activity and the cell cycle through Jab1. Nature. 2000;408:211-216.

17. Bacher M, Meinhardt A, Lan HY, et al. MIF expression in the rat brain: implications for neuronal function. Mol Med. 1998;4:217-230.

18. Conboy L, Varea E, Castro JE, et al. Macrophage migration inhibitory factor is critically involved in basal and fluoxetine-stimulated adult hippocampal cell proliferation and in anxiety, depression, and memoryrelated behaviors. Mol Psychiatry. 2011;16:533-547.

19. Bloom J, Al-Abed Y. MIF: mood improving/inhibiting factor? J Neuroinflammation. 2014;11:11.

20. Christian LM, Franco A, Iams JD, Sheridan J, Glaser R. Depressive symptoms predict exaggerated inflammatory responses to an in vivo immune challenge among pregnant women. Brain Behav Immun. 2010;24: $49-53$.

21. Musil R, Schwarz MJ, Riedel M, et al. Elevated macrophage migration inhibitory factor and decreased transforming growth factor-beta levels in major depression - no influence of celecoxib treatment. $J$ Affect Disord. 2011;134:217-225.

22. Zunszain PA, Hepgul N, Pariante CM. Inflammation and depression. Curr Top Behav Neurosci. 2013;14:135-151.

23. Bot M, Chan MK, Jansen R, et al. Serum proteomic profiling of major depressive disorder. Transl Psychiatry. 2015;5:e599. 
24. Stelzhammer V, Haenisch F, Chan MK, et al. Proteomic changes in serum of first onset, antidepressant drug-naive major depression patients. Int J Neuropsychopharmacol. 2014;17:1599-1608.

25. Edwards KM, Bosch JA, Engeland CG, Cacioppo JT, Marucha PT. Elevated macrophage migration inhibitory factor (MIF) is associated with depressive symptoms, blunted cortisol reactivity to acute stress, and lowered morning cortisol. Brain Behav Immun. 2010;24:1202-1208.

26. Coryell W, Schlesser M. The dexamethasone suppression test and suicide prediction. Am J Psychiatry. 2001;158:748-753.

27. Baugh JA, Chitnis S, Donnelly SC, et al. A functional promoter polymorphism in the macrophage migration inhibitory factor (MIF) gene associated with disease severity in rheumatoid arthritis. Genes Immun. 2002;3:170-176.

28. De Benedetti F, Meazza C, Vivarelli M, et al. Functional and prognostic relevance of the -173 polymorphism of the macrophage migration inhibitory factor gene in systemic-onset juvenile idiopathic arthritis. Arthritis Rheum. 2003;48:1398-1407.

29. Donn RP, Shelley E, Ollier WE, Thomson W; British Paediatric Rheumatology Study Group. A novel 5'-flanking region polymorphism of macrophage migration inhibitory factor is associated with systemic-onset juvenile idiopathic arthritis. Arthritis Rheum. 2001;44:1782-1785.

30. Lehmann LE, Book M, Hartmann W, et al. MIF haplotype is associated with the outcome of patients with severe sepsis: a case control study. J Transl Med. 2009; 7:100.

31. Wu J, Fu S, Ren X, et al. Association of MIF promoter polymorphisms with childhood asthma in a northeastern Chinese population. Tissue Antigens. 2009;73:302-306.

32. Wang FF, Huang XF, Shen N, et al. A genetic role for macrophage migration inhibitory factor (MIF) in adult-onset Still's disease. Arthritis Res Ther. 2013;15:R65.

33. Kuai SG, Ou QF, You DH, et al. Functional polymorphisms in the gene encoding macrophage migration inhibitory factor (MIF) are associated with active pulmonary tuberculosis. Infect Dis (Lond). 2016;48: 222-228.

34. Savva A, Brouwer MC, Roger T, et al. Functional polymorphisms of macrophage migration inhibitory factor as predictors of morbidity and mortality of pneumococcal meningitis. Proc Natl Acad Sci US A. 2016; 113:3597-3602.

35. Dumais A, Lesage AD, Lalovic A, et al. Is violent method of suicide a behavioral marker of lifetime aggression? Am J Psychiatry. 2005;162: 1375-1378.

36. Okazaki S, Watanabe Y, Hishimoto A, et al. Association analysis of putative cis-acting polymorphisms of interleukin-19 gene with schizophrenia. Prog Neuropsychopharmacol Biol Psychiatry. 2014;50: 151-156.
37. Otsuka I, Watanabe Y, Hishimoto A, et al. Association analysis of the Cadherin13 gene with schizophrenia in the Japanese population. Neuropsychiatr Dis Treat. 2015;11:1381-1393.

38. Barrett JC, Fry B, Maller J, Daly MJ. Haploview: analysis and visualization of LD and haplotype maps. Bioinformatics. 2005;21:263-265.

39. Dupont WD, Plummer WD. Power and sample size calculations for studies involving linear regression. Control Clin Trials. 1998;19: 589-601.

40. Canetto SS, Cleary A. Men, masculinities and suicidal behaviour. Soc Sci Med. 2012;74:461-465.

41. Shenassa ED, Catlin SN, Buka SL. Lethality of firearms relative to other suicide methods: a population based study. J Epidemiol Community Health. 2003;57:120-124.

42. Pivac N, Pregelj P, Nikolac M, et al. The association between catecholO-methyl-transferase Val108/158Met polymorphism and suicide. Genes Brain Behav. 2011;10:565-569.

43. Pregelj P, Nedic G, Paska AV, et al. The association between brainderived neurotrophic factor polymorphism (BDNF Val66Met) and suicide. J Affect Disord. 2011;128:287-290.

44. Major Depressive Disorder Working Group of the Psychiatric Gwas Consortium, Ripke S, Wray NR, Lewis CM, et al. A mega-analysis of genome-wide association studies for major depressive disorder. Mol Psychiatry. 2013;18:497-511.

45. Hyde CL, Nagle MW, Tian C, et al. Identification of 15 genetic loci associated with risk of major depression in individuals of European descent. Nat Genet. 2016;48:1031-1036.

46. Galfalvy H, Haghighi F, Hodgkinson C, et al. A genome-wide association study of suicidal behavior. Am J Med Genet B Neuropsychiatr Genet. 2015;168:557-563.

47. Llamas-Covarrubias MA, Valle Y, Bucala R, et al. Macrophage migration inhibitory factor (MIF): genetic evidence for participation in early onset and early stage rheumatoid arthritis. Cytokine. 2013;61: 759-765.

48. Swanberg M, McGuigan F, Ivaska KK, et al. Polymorphisms in the macrophage migration inhibitory factor gene and bone loss in postmenopausal women. Bone. 2010;47:424-429.

49. Bucala R. MIF, MIF alleles, and prospects for therapeutic intervention in autoimmunity. J Clin Immunol. 2013;33(Suppl 1):S72-S78. 


\section{Supplementary materials}

Table SI Association of MIF promoter polymorphisms with suicide completers and controls for males

\begin{tabular}{|c|c|c|c|c|c|c|c|c|}
\hline \multirow[t]{2}{*}{ Polymorphism } & \multicolumn{2}{|c|}{$\begin{array}{l}\text { Male suicide } \\
(n=408)\end{array}$} & \multicolumn{2}{|c|}{$\begin{array}{l}\text { Male control } \\
(n=340)\end{array}$} & \multirow[t]{2}{*}{$P$-value ${ }^{a}$} & \multirow[t]{2}{*}{$\begin{array}{l}\text { Global } \\
\text { P-value }\end{array}$} & \multirow[t]{2}{*}{ OR $(95 \% \mathrm{CI})$} & \multirow[t]{2}{*}{ Powe } \\
\hline & $\mathbf{N}$ & Frequency & $\mathbf{N}$ & Frequency & & & & \\
\hline \multicolumn{9}{|l|}{ MIF-794CATT $_{5-8}$} \\
\hline \multicolumn{9}{|l|}{ Genotype } \\
\hline 55 & 56 & 0.137 & 49 & 0.144 & 0.788 & 0.584 & $0.945(0.625-1.429)$ & 0.059 \\
\hline 56 & 159 & 0.390 & 119 & 0.350 & 0.263 & & I.186 (0.880-I.599) & 0.193 \\
\hline 57 & 53 & 0.130 & 44 & 0.129 & 0.984 & & $1.004(0.654-1.542)$ & 0.050 \\
\hline 66 & 77 & 0.189 & 77 & 0.226 & 0.204 & & $0.795(0.557-1.133)$ & 0.256 \\
\hline 67 & 53 & 0.130 & 38 & 0.112 & 0.450 & & I.I87 (0.76I-I.850) & 0.108 \\
\hline 77 & 10 & 0.025 & 13 & 0.038 & 0.279 & & $0.632(0.274-1.460)$ & 0.194 \\
\hline \multicolumn{9}{|l|}{ Allele } \\
\hline $\mathrm{CATT}_{5}$ & 324 & 0.397 & 261 & 0.384 & 0.601 & 0.875 & I.057 (0.858-I.303) & 0.080 \\
\hline $\mathrm{CATT}_{6}$ & 366 & 0.449 & 311 & 0.457 & 0.733 & & $0.965(0.787-1.184)$ & 0.061 \\
\hline $\mathrm{CATT}_{7}^{\circ}$ & 126 & 0.154 & 108 & 0.159 & 0.815 & & $0.967(0.73|-| .280)$ & 0.058 \\
\hline \multicolumn{9}{|l|}{ MIF-I73G/C } \\
\hline \multicolumn{9}{|l|}{ Genotype } \\
\hline GG & 252 & 0.618 & 218 & $0.64 I$ & 0.507 & 0.753 & $0.904(0.67|-| .2 \mid 8)$ & 0.100 \\
\hline GC & 136 & 0.333 & 102 & 0.300 & 0.330 & & I.I67 (0.856-I.59I) & 0.154 \\
\hline CC & 20 & 0.049 & 20 & 0.059 & 0.553 & & $0.825(0.436-1.560)$ & 0.097 \\
\hline \multicolumn{9}{|l|}{ Allele } \\
\hline G & 640 & 0.784 & 538 & 0.791 & 0.747 & & $0.960(0.748-|.23|)$ & 0.062 \\
\hline $\mathrm{C}$ & 176 & 0.216 & 142 & 0.209 & & & & \\
\hline \multicolumn{9}{|l|}{ Haplotype } \\
\hline MIFCATT $_{5}-173 \mathrm{G}$ & 283 & 0.347 & 234.1 & 0.344 & 0.920 & 0.769 & $1.011(0.816-1.253)$ & 0.052 \\
\hline MIFCATT $_{6}-173 \mathrm{G}$ & 357.4 & 0.438 & 300.6 & 0.442 & 0.875 & & $0.984(0.80 I-I .207)$ & 0.053 \\
\hline MIFCATT $_{7}-173 \mathrm{G}$ & 2.1 & 0.003 & 0.1 & 0.000 & 0.208 & & 17.54 (0.03 I-9.989) & 0.000 \\
\hline MIFCATT $_{5}-173 \mathrm{C}$ & 41 & 0.050 & 26.9 & 0.040 & 0.320 & & $1.284(0.78 I-2.1 \mid 2)$ & 0.132 \\
\hline MIFCATT $_{6}-173 \mathrm{C}$ & 8.6 & 0.011 & 10.4 & 0.015 & 0.413 & & $0.686(0.276-1.702)$ & 0.111 \\
\hline MIFCATT $_{7}-173 \mathrm{C}$ & 123.9 & 0.152 & 107.9 & 0.159 & 0.715 & & $0.949(0.7 \mid 7-1.257)$ & 0.067 \\
\hline
\end{tabular}

Notes: ${ }^{\text {P }}$-values were tested with the $\chi^{2}$ test. ' ${ }^{b}$ Global $P$-value was calculated by Fisher's exact test or Cochran-Armitage test for trend, as appropriate.

Abbreviations: MIF, macrophage migration inhibitory factor; OR, odds ratio; $\mathrm{Cl}$, confidence interval.

Table S2 Association of MIF promoter polymorphisms with suicide completers and controls for females

\begin{tabular}{|c|c|c|c|c|c|c|c|c|}
\hline \multirow[t]{2}{*}{ Polymorphism } & \multicolumn{2}{|c|}{$\begin{array}{l}\text { Female suicide } \\
(\mathrm{n}=194)\end{array}$} & \multicolumn{2}{|c|}{$\begin{array}{l}\begin{array}{l}\text { Female control } \\
(n=388)\end{array} \\
\end{array}$} & \multirow[t]{2}{*}{$P$-value ${ }^{a}$} & \multirow[t]{2}{*}{$\begin{array}{l}\text { Global } \\
\text { P-value }\end{array}$} & \multirow[t]{2}{*}{ OR (95\% Cl) } & \multirow[t]{2}{*}{ Power } \\
\hline & $\mathbf{N}$ & Frequency & $\mathbf{N}$ & Frequency & & & & \\
\hline \multicolumn{9}{|l|}{ MIF-794CATT $_{5-8}$} \\
\hline \multicolumn{9}{|l|}{ Genotype } \\
\hline 55 & 30 & 0.155 & 56 & 0.144 & $0.74 I$ & 0.850 & I.084 (0.670-I.755) & 0.066 \\
\hline 56 & 72 & 0.371 & 132 & 0.340 & 0.461 & & I.I 45 (0.799-I.639) & 0.114 \\
\hline 57 & 24 & 0.124 & 51 & 0.131 & 0.793 & & $0.933(0.555-1.568)$ & 0.055 \\
\hline 66 & 34 & 0.175 & 81 & 0.209 & 0.339 & & $0.805(0.5|7-| .255)$ & 0.162 \\
\hline 67 & 30 & 0.155 & 55 & 0.142 & 0.678 & & I. 108 (0.684-I.794) & 0.072 \\
\hline 77 & 4 & 0.021 & 13 & 0.034 & 0.384 & & $0.607(0.195-1.888)$ & 0.119 \\
\hline \multicolumn{9}{|l|}{ Allele } \\
\hline $\mathrm{CATT}_{5}$ & 156 & 0.402 & 295 & 0.380 & 0.470 & 0.762 & I.096 (0.854-I.407) & 0.112 \\
\hline $\mathrm{CATT}_{6}$ & 170 & 0.438 & 349 & 0.450 & 0.708 & & $0.954(0.746-1.219)$ & 0.067 \\
\hline $\mathrm{CATT}_{7}^{\circ}$ & 62 & 0.160 & 132 & 0.170 & 0.656 & & $0.928(0.667-1.290)$ & 0.070 \\
\hline \multicolumn{9}{|l|}{ MIF-I73G/C } \\
\hline \multicolumn{9}{|l|}{ Genotype } \\
\hline GG & 121 & 0.624 & 233 & 0.601 & 0.589 & 0.390 & I. $103(0.774-1.572)$ & 0.082 \\
\hline GC & 67 & 0.345 & 135 & 0.348 & 0.951 & & $0.989(0.688-1.420)$ & 0.050 \\
\hline $\mathrm{CC}$ & 6 & 0.031 & 20 & 0.052 & 0.256 & & $0.587(0.232-1.487)$ & 0.196 \\
\hline
\end{tabular}


Table S2 (Continued)

\begin{tabular}{|c|c|c|c|c|c|c|c|c|}
\hline \multirow[t]{2}{*}{ Polymorphism } & \multicolumn{2}{|c|}{$\begin{array}{l}\text { Female suicide } \\
(n=194)\end{array}$} & \multicolumn{2}{|c|}{$\begin{array}{l}\text { Female control } \\
(n=388)\end{array}$} & \multirow[t]{2}{*}{$P$-value ${ }^{a}$} & \multirow[t]{2}{*}{$\begin{array}{l}\text { Global } \\
P \text {-value }\end{array}$} & \multirow[t]{2}{*}{ OR $(95 \% \mathrm{Cl})$} & \multirow[t]{2}{*}{ Power } \\
\hline & $\mathbf{N}$ & Frequency & $\mathbf{N}$ & Frequency & & & & \\
\hline \multicolumn{9}{|l|}{ Allele } \\
\hline G & 309 & 0.796 & 601 & 0.774 & 0.394 & & $1.139(0.845-1.536)$ & 0.089 \\
\hline C & 79 & 0.204 & 175 & 0.226 & & & & \\
\hline \multicolumn{9}{|l|}{ Haplotype } \\
\hline MIFCATT $_{5}-173 \mathrm{G}$ & 143.7 & 0.370 & 262.6 & 0.338 & 0.280 & 0.519 & I.I50 (0.892-I.483) & 0.187 \\
\hline MIFCATT $_{6}-173 \mathrm{G}$ & 164.3 & 0.423 & 340.6 & 0.439 & 0.615 & & $0.939(0.734-1.20 I)$ & 0.081 \\
\hline MIFCATT $_{7}-173 \mathrm{G}$ & 2.1 & 0.005 & I.I & 0.001 & 0.233 & & $3.834(0.380-38.62)$ & 0.071 \\
\hline MIFCATT $_{5}-173 \mathrm{C}$ & 12.3 & 0.032 & 32.4 & 0.042 & 0.398 & & $0.75 \mid(0.385-\mid .465)$ & 0.124 \\
\hline MIFCATT $_{6}-173 \mathrm{C}$ & 5.7 & 0.015 & 8.4 & 0.011 & 0.564 & & $1.362(0.467-3.975)$ & 0.092 \\
\hline MIFCATT $_{7}-173 \mathrm{C}$ & 59.9 & 0.154 & 130.9 & 0.169 & 0.538 & & $0.900(0.645-1.256)$ & 0.098 \\
\hline
\end{tabular}

Notes: ${ }^{a}$-values were tested with the $\chi^{2}$ test. ${ }^{b} \mathrm{Global} P$-value was calculated by Fisher's exact test or Cochran-Armitage test for trend, as appropriate. Abbreviations: MIF, macrophage migration inhibitory factor; OR, odds ratio; $\mathrm{Cl}$, confidence interval.

Table S3 Association of MIF promoter polymorphisms with violent suicide completers and controls

\begin{tabular}{|c|c|c|c|c|c|c|c|c|}
\hline \multirow[t]{2}{*}{ Polymorphism } & \multicolumn{2}{|c|}{$\begin{array}{l}\text { Violent suicide } \\
(n=568)\end{array}$} & \multicolumn{2}{|c|}{$\begin{array}{l}\text { Control } \\
(n=728)\end{array}$} & \multirow[t]{2}{*}{$P$-value ${ }^{a}$} & \multirow[t]{2}{*}{$\begin{array}{l}\text { Global } \\
P \text {-value }\end{array}$} & \multirow[t]{2}{*}{ OR $(95 \% \mathrm{CI})$} & \multirow[t]{2}{*}{ Power } \\
\hline & $\mathbf{N}$ & Frequency & $\mathbf{N}$ & Frequency & & & & \\
\hline \multicolumn{9}{|l|}{ MIF-794CATT $_{5-8}$} \\
\hline \multicolumn{9}{|l|}{ Genotype } \\
\hline 55 & 82 & 0.144 & 105 & 0.144 & 0.995 & 0.313 & I.00I (0.733-I.368) & 0.050 \\
\hline 56 & 220 & 0.387 & 251 & 0.345 & 0.114 & & I.20I (0.957-I.509) & 0.329 \\
\hline 57 & 70 & 0.123 & 95 & 0.130 & 0.697 & & $0.937(0.673-1.303)$ & 0.066 \\
\hline 66 & 105 & 0.185 & 158 & 0.217 & 0.153 & & $0.8 \mid 8(0.62|-| .078)$ & 0.309 \\
\hline 67 & 79 & 0.139 & 93 & 0.128 & 0.551 & & $1.103(0.799-1.522)$ & 0.088 \\
\hline 77 & 12 & 0.021 & 26 & 0.036 & 0.122 & & $0.583(0.291-1.165)$ & 0.387 \\
\hline \multicolumn{9}{|l|}{ Allele } \\
\hline $\mathrm{CATT}_{5}$ & 454 & 0.400 & 556 & 0.382 & 0.357 & 0.554 & $1.078(0.919-1.263)$ & 0.152 \\
\hline $\mathrm{CATT}_{6}$ & 509 & 0.448 & 660 & 0.453 & 0.791 & & $0.979(0.838-1.144)$ & 0.057 \\
\hline $\mathrm{CATT}_{7}$ & 173 & 0.152 & 240 & 0.165 & 0.387 & & $0.910(0.736-1.126)$ & 0.148 \\
\hline \multicolumn{9}{|l|}{ MIF-I73G/C } \\
\hline \multicolumn{9}{|l|}{ Genotype } \\
\hline GG & 355 & 0.625 & 451 & 0.620 & 0.840 & 0.542 & $1.024(0.8 \mid 6-1.284)$ & 0.054 \\
\hline GC & 190 & 0.335 & 237 & 0.326 & 0.734 & & I.04I (0.825-I.3I5) & 0.063 \\
\hline $\mathrm{CC}$ & 23 & 0.040 & 40 & 0.055 & 0.230 & & $0.726(0.429-1.227)$ & 0.250 \\
\hline \multicolumn{9}{|l|}{ Allele } \\
\hline G & 900 & 0.792 & 1,139 & 0.782 & 0.539 & & I.06I (0.878-I.283) & 0.094 \\
\hline C & 236 & 0.208 & 317 & 0.218 & & & & \\
\hline \multicolumn{9}{|l|}{ Haplotype } \\
\hline MIFCATT $_{5}-173 \mathrm{G}$ & 406.8 & 0.358 & 496.7 & $0.34 I$ & 0.369 & 0.547 & $1.077(0.916-1.268)$ & 0.145 \\
\hline MIFCATT $_{6}-173 \mathrm{G}$ & 494.8 & 0.436 & 640.9 & 0.440 & 0.812 & & $0.98 \mid(0.839-|| 48)$. & 0.055 \\
\hline MIFCATT $_{7}-173 \mathrm{G}$ & 4.1 & 0.004 & 1.2 & 0.001 & 0.113 & & $4.391(0.573-33.63)$ & 0.057 \\
\hline MIFCATT $_{5}-173 \mathrm{C}$ & 47.2 & 0.042 & 59.3 & 0.041 & 0.915 & & 1.021 (0.69I-I.509) & 0.052 \\
\hline MIFCATT $_{6}-173 \mathrm{C}$ & 14.2 & 0.013 & 19.1 & 0.013 & 0.900 & & $0.952(0.477-1.90 I)$ & 0.050 \\
\hline MIFCATT $_{7}-173 \mathrm{C}$ & 168.9 & 0.149 & 238.8 & 0.164 & 0.286 & & $0.890(0.718-1.103)$ & 0.184 \\
\hline
\end{tabular}

Notes: ${ }^{a}$-values were tested with the $\chi^{2}$ test. ${ }^{b} G$ lobal $P$-value was calculated by Fisher's exact test or Cochran-Armitage test for trend, as appropriate.

Abbreviations: MIF, macrophage migration inhibitory factor; OR, odds ratio; $\mathrm{Cl}$, confidence interval. 
Table S4 Association of MIF promoter polymorphisms with nonviolent suicide completers and controls

\begin{tabular}{|c|c|c|c|c|c|c|c|c|}
\hline \multirow[t]{2}{*}{ Polymorphism } & \multicolumn{2}{|c|}{$\begin{array}{l}\text { Nonviolent suicide } \\
(n=10)\end{array}$} & \multicolumn{2}{|c|}{$\begin{array}{l}\text { Control } \\
(n=728)\end{array}$} & \multirow[t]{2}{*}{$P$-value ${ }^{a}$} & \multirow[t]{2}{*}{$\begin{array}{l}\text { Global } \\
P \text {-value }\end{array}$} & \multirow[t]{2}{*}{ OR $(95 \% \mathrm{Cl})$} & \multirow[t]{2}{*}{ Power } \\
\hline & $\mathbf{N}$ & Frequency & $\mathbf{N}$ & Frequency & & & & \\
\hline \multicolumn{9}{|l|}{ MIF-794CATT $_{5-8}$} \\
\hline \multicolumn{9}{|l|}{ Genotype } \\
\hline 55 & I & 0.100 & 105 & 0.144 & 0.692 & 0.890 & $0.659(0.083-5.258)$ & 0.037 \\
\hline 56 & 5 & 0.500 & 251 & 0.345 & 0.306 & & $1.900(0.545-6.626)$ & 0.187 \\
\hline 57 & 1 & 0.100 & 95 & 0.130 & 0.776 & & $0.740(0.093-5.910)$ & 0.036 \\
\hline 66 & 1 & 0.100 & 158 & 0.217 & 0.371 & & $0.40 I(0.050-3.188)$ & 0.073 \\
\hline 67 & 2 & 0.200 & 93 & 0.128 & 0.498 & & $1.707(0.357-8.161)$ & 0.152 \\
\hline 77 & 0 & 0.000 & 26 & 0.036 & 0.543 & & - & - \\
\hline \multicolumn{9}{|l|}{ Allele } \\
\hline $\mathrm{CATT}_{5}$ & 8 & 0.400 & 556 & 0.382 & 0.868 & 1.000 & $1.079(0.438-2.656)$ & 0.055 \\
\hline $\mathrm{CATT}_{6}$ & 9 & 0.450 & 660 & 0.453 & 0.977 & & $0.987(0.406-2.396)$ & 0.050 \\
\hline $\mathrm{CATT}_{7}$ & 3 & 0.150 & 240 & 0.165 & 0.859 & & $0.894(0.260-3.075)$ & 0.045 \\
\hline \multicolumn{9}{|l|}{ MIF-I73G/C } \\
\hline \multicolumn{9}{|l|}{ Genotype } \\
\hline GG & 6 & 0.600 & 451 & 0.620 & 0.840 & 0.852 & $0.921(0.258-3.294)$ & 0.054 \\
\hline GC & 4 & 0.400 & 237 & 0.326 & 0.874 & & I.38I (0.386-4.94I) & 0.089 \\
\hline CC & 0 & 0.000 & 40 & 0.055 & 0.953 & & - & - \\
\hline \multicolumn{9}{|l|}{ Allele } \\
\hline G & 16 & 0.800 & 1,139 & 0.782 & 0.935 & & $1.113(0.370-3.353)$ & 0.047 \\
\hline $\mathrm{C}$ & 4 & 0.200 & 317 & 0.218 & & & & \\
\hline \multicolumn{9}{|l|}{ Haplotype } \\
\hline MIFCATT $_{5}-$ I73G & 6.8 & 0.340 & 496.6 & $0.34 I$ & 0.980 & 0.971 & $0.995(0.392-2.526)$ & 0.050 \\
\hline MIFCATT $_{6}-173 \mathrm{G}$ & 8.9 & 0.445 & 641.2 & 0.440 & 0.965 & & $1.019(0.419-2.476)$ & 0.050 \\
\hline MIFCATT $_{7}-173 \mathrm{G}$ & 0.0 & 0.000 & 1.0 & 0.001 & 0.907 & & - & - \\
\hline MIFCATT $_{5}-173 \mathrm{C}$ & 1.2 & 0.060 & 59.4 & $0.04 I$ & 0.642 & & I.50I (0.233-9.675) & 0.120 \\
\hline MIFCATT $_{6}^{5}-173 \mathrm{C}$ & 0.1 & 0.005 & 18.8 & 0.013 & 0.744 & & $0.384(0.001-195.1)$ & 0.004 \\
\hline MIFCATT $_{7}-173 \mathrm{C}$ & 3.0 & 0.150 & 239.0 & 0.164 & 0.863 & & $0.899(0.26 \mathrm{I}-3.090)$ & 0.045 \\
\hline
\end{tabular}

Notes: a ${ }^{P}$-values were tested with the $\chi^{2}$ test. ${ }^{b} \mathrm{Global} P$-value was calculated by Fisher's exact test or Cochran-Armitage test for trend, as appropriate.

Abbreviations: MIF, macrophage migration inhibitory factor; OR, odds ratio; $\mathrm{Cl}$, confidence interval.

Table S5 Association of MIF promoter polymorphisms with violent and nonviolent suicide completers

\begin{tabular}{|c|c|c|c|c|c|c|c|c|}
\hline \multirow[t]{2}{*}{ Polymorphism } & \multicolumn{2}{|c|}{$\begin{array}{l}\text { Violent suicide } \\
(\mathrm{n}=568)\end{array}$} & \multicolumn{2}{|c|}{$\begin{array}{l}\text { Nonviolent suicide } \\
(\mathrm{n}=10)\end{array}$} & \multirow[t]{2}{*}{$P$-value ${ }^{a}$} & \multirow[t]{2}{*}{$\begin{array}{l}\text { Global } \\
P \text {-value }\end{array}$} & \multirow[t]{2}{*}{ OR (95\% Cl) } & \multirow[t]{2}{*}{ Power } \\
\hline & $\mathbf{N}$ & Frequency & $\mathbf{N}$ & Frequency & & & & \\
\hline \multicolumn{9}{|l|}{ MIF-794CATT $_{5-8}$} \\
\hline \multicolumn{9}{|l|}{ Genotype } \\
\hline 55 & 82 & 0.144 & 1 & 0.100 & 0.692 & 0.940 & $1.519(0.190-12.15)$ & 0.032 \\
\hline 56 & 220 & 0.387 & 5 & 0.500 & 0.469 & & $0.632(0.18 I-2.209)$ & 0.134 \\
\hline 57 & 70 & 0.123 & I & 0.100 & 0.824 & & $1.265(0.158-10.13)$ & 0.036 \\
\hline 66 & 105 & 0.185 & 1 & 0.100 & 0.492 & & $2.04 \mid(0.256-16.29)$ & 0.031 \\
\hline 67 & 79 & 0.139 & 2 & 0.200 & 0.582 & & $0.646(0.135-3.099)$ & 0.139 \\
\hline 77 & 12 & 0.021 & 0 & 0.000 & 0.642 & & - & \\
\hline \multicolumn{9}{|l|}{ Allele } \\
\hline $\mathrm{CATT}_{5}$ & 454 & 0.400 & 8 & 0.400 & 0.998 & 1.000 & $0.999(0.405-2.462)$ & 0.050 \\
\hline $\mathrm{CATT}_{6}$ & 509 & 0.448 & 9 & 0.450 & 0.986 & & $0.992(0.408-2.413)$ & 0.050 \\
\hline $\mathrm{CATT}_{7}$ & 173 & 0.152 & 3 & 0.150 & 0.978 & & $1.018(0.295-3.511)$ & 0.049 \\
\hline
\end{tabular}


Table S5 (Continued)

\begin{tabular}{|c|c|c|c|c|c|c|c|c|}
\hline \multirow[t]{2}{*}{ Polymorphism } & \multicolumn{2}{|c|}{$\begin{array}{l}\text { Violent suicide } \\
(n=568)\end{array}$} & \multicolumn{2}{|c|}{$\begin{array}{l}\text { Nonviolent suicide } \\
(n=10)\end{array}$} & \multirow[t]{2}{*}{$P$-value ${ }^{a}$} & \multirow[t]{2}{*}{$\begin{array}{l}\text { Global } \\
\text { P-value }\end{array}$} & \multirow[t]{2}{*}{ OR (95\% CI) } & \multirow[t]{2}{*}{ Power } \\
\hline & $\mathbf{N}$ & Frequency & $\mathbf{N}$ & Frequency & & & & \\
\hline \multicolumn{9}{|l|}{ MIF-I73G/C } \\
\hline \multicolumn{9}{|l|}{ Genotype } \\
\hline GG & 355 & 0.625 & 6 & 0.600 & 0.871 & 0.932 & I.III (0.3।0-3.982) & 0.056 \\
\hline GC & 190 & 0.335 & 4 & 0.400 & 0.664 & & $0.754(0.210-2.704)$ & 0.085 \\
\hline $\mathrm{CC}$ & 23 & 0.040 & 0 & 0.000 & 0.516 & & - & - \\
\hline \multicolumn{9}{|l|}{ Allele } \\
\hline $\mathrm{G}$ & 900 & 0.792 & 16 & 0.800 & 0.933 & & $0.953(0.316-2.878)$ & 0.048 \\
\hline C & 236 & 0.208 & 4 & 0.200 & & & & \\
\hline \multicolumn{9}{|l|}{ Haplotype } \\
\hline MIFCATT $_{5}-173 \mathrm{G}$ & 406.0 & 0.357 & 6.8 & 0.340 & 0.858 & 0.973 & $1.080(0.425-2.745)$ & 0.050 \\
\hline MIFCATT $_{6}-I 73 \mathrm{G}$ & 494.6 & 0.435 & 8.9 & 0.445 & 0.932 & & $0.962(0.395-2.341)$ & 0.051 \\
\hline MIFCATT $_{7}-I 73 G$ & 4.3 & 0.004 & 0.0 & 0.000 & 0.800 & & - & - \\
\hline MIFCATT $_{5}-173 \mathrm{C}$ & 48.0 & 0.042 & 1.2 & 0.060 & 0.666 & & $0.691(0.107-4.475)$ & 0.121 \\
\hline MIFCATT $_{6}^{3}-I 73 \mathrm{C}$ & 14.4 & 0.013 & 0.1 & 0.005 & 0.760 & & $2.555(0.005-1.304)$ & 0.003 \\
\hline MIFCATT $_{7}-I 73 \mathrm{C}$ & 168.7 & 0.149 & 3.0 & 0.150 & 0.988 & & $0.988(0.287-3.409)$ & 0.051 \\
\hline
\end{tabular}

Notes: ${ }^{a} P$-values were tested with the $\chi^{2}$ test. ${ }^{b} G$ lobal $P$-value was calculated by Fisher's exact test or Cochran-Armitage test for trend, as appropriate.

Abbreviations: MIF, macrophage migration inhibitory factor; OR, odds ratio; $\mathrm{Cl}$, confidence interval.

\section{Publish your work in this journal}

Neuropsychiatric Disease and Treatment is an international, peerreviewed journal of clinical therapeutics and pharmacology focusing on concise rapid reporting of clinical or pre-clinical studies on a range of neuropsychiatric and neurological disorders. This journal is indexed on PubMed Central, the 'PsycINFO' database and CAS, and is the official journal of The International Neuropsychiatric Association (INA). The manuscript management system is completely online and includes a very quick and fair peer-review system, which is all easy to use. Visit http://www.dovepress.com/testimonials.php to read real quotes from published authors.

\footnotetext{
Submit your manuscript here: http://www.dovepress.com/neuropsychiatric-disease-and-treatment-journal
} 